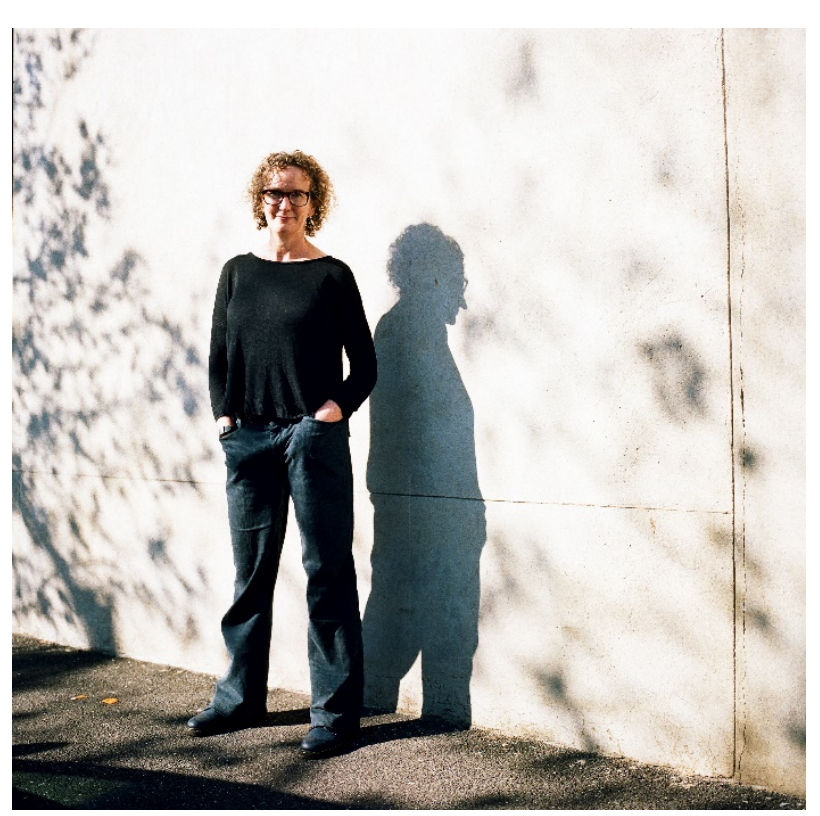

\title{
On human and non-human people: an interview with Jane Rawson
}

Patrick Allington

Australian fiction writer Jane Rawson writes about strange but familiar worlds. Her books and stories are relentlessly inventive, disruptive but tender and funny, and thoroughly thoughtprovoking. Her debut novel, A wrong turn at the Office of Unmade Lists (Transit Lounge, 2013), was shortlisted in the science fiction category for the 2013 Aurealis Awards and won the Small Press Network's 'Most Underrated Book Award'. This was followed by two books in 2015, a novella, Formaldehyde (2015, winner of the Seizure Viva la Novella competition), and the nonfiction work The Handbook: Surviving and Living with Climate Change (Transit Lounge, cowritten with James Whitmore). Her novel From the Wreck, the main topic of this interview, was published by Transit Lounge (Melbourne) in 2017 and by Picador (UK) in 2019. It won the Aurealis Award for Best Science Fiction Novel, was longlisted for the Miles Franklin Literary Award, and shortlisted for the Barbara Jeffries Award, the Readings Prize for New Australian Fiction and the Adelaide Festival Awards for Literature. This interview took place before a live audience at Imprints Booksellers in Hindley Street, Adelaide, in 2018, and was updated via email exchange between the interviewer and Jane Rawson.

Patrick Allington: Is it a good thing to win a 'most underrated book award', as you did for $A$ wrong turn at the Office of Unmade Lists (2013)?

Jane Rawson: It is. But I feel like as soon as you win it you have to give it back because someone else is then more underrated than you are. It's a paradox. 
PA: So, you're underrated until you win the Award, and then you're not underrated?

JR: Yep.

PA: We're going to mainly - but not entirely - talk about what I think I'm fair in calling a very strange novel: From the Wreck. It is a strange novel, isn't it?

JR: Yes.

PA: So, colonial South Australia, in particular colonial Port Adelaide; the Admella steamship, which in 1859 in the real world went down on Carpenter's Reef off the coast of South Australia, near Mount Gambier; a survivor of that wreck, George Hills - a real life survivor and a real life relative of yours. So that's what you started with: can you tell us the first version of this book?

JR: So, yes, I set out to write a historical fiction novel about my Great-great Grandfather, George Hills, who was wrecked on the Admella in 1859 in the middle of winter. The wreck was semi-submerged, stranded on this reef for eight days and nights, with a little bit of food, pretty much no water. They had a little bit of beer - tiny bit -

PA: Is that the sense in which he was 'wrecked'?

JR: Yeah, he was wrecked! And he was a steward on this ship, so, essentially fulfilling the role that the women on planes - generally women - do, where they bring you food and stuff. Just a regular guy: twenty-four.

PA: And the plane's a good analogy, because this ship went back and forth?

JR: Back and forth. Passengers, cargo, just like regular flights now. So, he's not a particularly brave man - he's not like Ernest Hemingway out there.

PA: Thank goodness for that.

JR: He was just some guy. And he survived this hideous experience, seeing almost everyone around him die: drown, die of exhaustion, go crazy, throw themselves off the boat - sharks everywhere. Eventually he was rescued, taken back home, and went out to sea again because that was his job, and got shipwrecked again, and went out to sea again, and then eventually took a job on land and had a family. I wanted to write something, to think about how that might be, to live through something like that in the Victorian era, South Australia, without psychology and he wasn't religious either. How do you live with that?

PA: How much did it weigh on you, this idea that very few people survived this wreck, and if he didn't survive you're not here trying to work out how to write his story?

JR: That was very much one of the reasons that I wanted to write it. I felt like he'd lived through this thing. He didn't have children until afterwards, so, yeah, I would not have existed had he died. I mean, I wouldn't have known that I didn't exist because I wouldn't exist. But, still, I did want to create something that would do justice to that sort of weird 
everyday kind of bravery - just chucked into a situation and dealing with it, whereas I struggle to deal with a perfectly nice life. Every single day I'm freaked out by it.

PA: So, you start. You're writing historical fiction. You're trying to be faithful to the story as you know it ...

JR: Yeah, which is only a little. There's not much known about this guy. He's not famous.

PA: And faithful to the era, faithful to the known world as we might understand it. And that wasn't working for you?

JR: No, I'm not good at it, as it turns out. It was not a good book. It was boring. It had the 'mmmm, old timey' feel about it. It just feels so fake and weird: and there are plenty of published books that have it, so maybe it could have got published, but it just felt ehhhr to me. I was very unhappy with it.

PA: Did you show it to other people and did they go ehhhr?

JR: I showed it to my mum and she went, 'Oh, this is lovely.'

PA: Did you show it to anyone else other than your mum?

JR: I showed it to my brother but he never told me what he thought of it - but my mum said, 'Your brother said it was very boring'. ... Also, I sent it to my publisher. He was ... he just kind of didn't really comment on it at all.

PA: Maybe he hasn't read it yet.

JR: I don't think he did. I think he read the first chapter and was like, 'I'll look at that later.'

PA: So, you didn't want to abandon the project?

JR: I kind of did abandon the project for a while, and I got a tattoo instead, of the wreck and my Great-great Grandfather, and it was like, 'Right, I've done him justice.' Yeah.

PA: But no...?

JR: It turns out no.

PA: So you come back to the story again. What's different this time? So, there's a woman, Bridget Ledwith, on the ship - and that's true? There was such a woman?

JR: There was such a woman.

PA: Your Bridget is -

JR: Different. 
PA: Not so human ...

JR: Well, I don't know what she was like in real life. Maybe my version is true by accident. ... I started writing a different story. I was just mucking around with a voice and I started writing the voice of this alien out in space looking for refuge. And I mucked around with that for a while, and then I had to do something with it, and I was like, 'What if this alien ended up on a shipwreck in 1859? How might that work?' But I was just mucking around.

\section{PA: But not mucking around with this story necessarily in mind?}

JR: Not to start with, no. When I started writing this alien character I was not planning to put her into this book. But then I got to the end of that story and I wanted to keep going. So I thought, 'What if Bridget Ledwith, who was a very mysterious character - in real life, she was the only woman survivor of this wreck, right after she was rescued she vanished. And then a number of different women claimed to be her. It was never really resolved what had happened to her. So that was a nice opening. And in fact it was my tattooist who said to me, 'She sounds spooky. I think she's potentially spooky.' And I thought, well, maybe she is. So I thought l'd make her into a shape-shifting alien instead. Had a go at that, chucking a shapeshifting alien into this book. Make her Bridget Ledwith. My Great-great Grandfather meets her, is bewitched by her in some way and then she just vanishes. And he is like, 'WHAT?'

PA: So, we've still got, on the one hand, a faithful historical novel, and we've got a shapeshifting alien.

JR: Yes, who is an octopus primarily.

PA: There's sense of mystery from the start, but a reader can get through the first chapter without sensing just how strange it's going to go. Is that deliberate?

JR: When I first finished a draft of that manuscript, I opened with the alien. And one of my early readers said, 'If you're showing this to publishers, you want to suck'em in with the historical fiction. They're gonna like that better. Suck 'em in and then hit them with the alien, once they're already locked in.' Which was a great idea. So, yes.

PA: So, yes, for publishers, but for readers as well?

JR: Yes. Well, I didn't think there would be readers. I was like, will this even ever get published? But I do think for readers too, it sets you off on a journey within ten pages, you're like 'Wait a second, what is this?' That's a nice feeling.

PA: When you say, 'I didn't think there'd be readers', is that self-deprecation or were you actually thinking 'This is a bit weird'?

JR: When you said 'this is a really strange novel', yeah. Even though my publisher had previously published $A$ Wrong Turn at the Office of Unmade Lists (Transit Lounge, 2013), which is not a normal novel either, I felt like this was a whole other level of oddness. And I 
didn't think my publisher would be particularly interested in it, and I couldn't see why anyone would want to read it. But I really wanted to write it. I really wanted to do this exercise. So, I did it.

PA: If you're doing it with that sense of abandon, is that a different feeling.

JR: Well, it's been a while since From the Wreck came out and I haven't seriously started something new. I think that might partly be because of that feeling that 'Well, some people paid attention to this and maybe they'll pay attention to the next thing, but I don't know what it should be.' It'd be quite nice to go back to that feeling.

PA: You could start something else you weren't enjoying ...

JR: Yes. Well, I have done that actually. I've written about 50,000 words of something I don't like very much.

PA: Good progress, then.

JR: Yeah.

PA: Tell us about George - we'll come back to the alien. What sort of life does George have and, in particular, how does he get on? How does he deal with the fact of his survival?

JR: He is quite angry. The first two times I wrote this he was a very nice man. He was lovely. He was really nice.

PA: Well, he's your relative.

JR: I know, I know. And he's not so nice in the book, except that I still feel like he'd like to be. He is angry at this woman he met. He's angry about how he feels about her. He doesn't like his child very much. He does like his wife, but she has a small part (sorry). The women in this book - there's hardly any. He's panicky all the time and he doesn't know why. He's mentally ill. He's anxious. He's furious with everything. He's not coping well.

PA: And he's clear in his mind that the woman he encountered on the ship and then shared space with as most of the ship was breaking up around them, is not a normal human being.

JR: Yes, he believes that. In some senses, it's a justification for him. He's putting the blame on her for how terrible he feels, for the fact that maybe he did a bit of light cannibalisation while he was on the boat. By saying that she is some sort of terrible witch who possessed him and made this happen, it helps him push away and not take responsibility for who he is. But he's sure that there's something off about her.

PA: So then his struggles in the real world, and in his day to day life - you may not be able to answer this, I may need to ask him - how much of it is because of this strange encounter and how much is it just the fact of surviving something that so many people didn't survive? 
JR: Ahhhh: yep. ... I think part of it is some sort of survivor guilt, although being in a shipwreck was reasonably common among the people he knew back then. But this was a particularly nasty one. Part of it is this weird experience that he's been through that he can't explain. But I think part of it, also, is having had this child who he finds very difficult to love and has this very tortured relationship with.

PA: And he's quite suspicious of the boy.

JR: He's very suspicious of his son. He thinks that he carries some kind of stain or mark from his experience and it's there to torture him in some way.

PA: And (spoiler alert) that may or may not be true.

JR: Right.

PA: So, that's George. How does the shape-shifting alien deal with having been on this shipwreck?

JR: For her, this is a small experience in the horror of her life. She has grown up on a planet where she had many relationships. She was loved. She had a full life. This is in another dimension. The time stuff in this is weird: glide over it. (I tried to keep it to a minimum, but in my head I know what happened.) Her planet has been destroyed by human-type people, who have destroyed their own planet, come to her planet, terraformed it to make it nice for humans. It was mostly ocean before they got there, and now it's mostly land. Basically, she has nowhere to live anymore and everyone she knows is dead. She and her few remaining friends have gone out into space and tried to find somewhere new to be. And she's lost them all along the way. She's completely alone. The last one left of her species. She's on this strange planet. She meets this guy. She hangs out with him a bit. She helps him survive. You'd think he was her friend. But he's not. He hates her and every time she tries to come to him in a different shape he's awful to her. She just feels lost and abandoned and in terrible despair. She's sad.

PA: How did you go about creating and mastering the voice of the alien, so that it was the voice you wanted it to be, it was a being you wanted it to be, it was communicating on its own terms in the way you wanted it to?

JR: You know how writers talk about how they wrote the novel and have no idea? So: when I first started writing it, all I had in my head was a picture of ... I had this strange picture on my desktop, on my computer, of a dead cosmonaut floating through space. And there's just stars and blackness all around this body. All I was interested in was writing something that was in a place of complete quiet. And that was what I started doing. Trying to do that. And I'd been thinking a lot about octopuses and reading a lot about octopuses and was a little obsessed with them. And so I wanted to put elements of that, particularly the shape-shifting and the sensing the world through every part of you instead of like we do mostly: through our head region. That's where it came from. I kind of had to self-hypnotise to do it. I wrote a lot of it at like 5 o'clock in the morning. I'd do it first thing, as soon as I woke up, try not to think about 
any of the real world and just flow. Editing it was harder. But I had an amazingly good editor, Penelope Goodes, who was working for Transit Lounge. She totally grasped what I was trying to do but could stand outside it and go, 'Okay, just this little bit needs a tweak so that people can understand what's going on here'.

PA: Did you know when you'd found the voice?

JR: Yes. Yes. It's a very physical kind of feeling of just knowing 'this is right', 'this is good'. She's very real to me.

PA: One of the things I find fascinating about her is that she inhabits these different entities. At one stage, she's an octopus. She has to think her way into that - what is this shape? Can you talk about that?

JR: The parts I enjoyed most are the parts where she is cat-like. That was a very fun physicality to inhabit.

PA: She was George's cat.

JR: She was George's cat for a while. And George really liked his cat. That was one time when they got on really well. It's fun writing in the shape of an animal. It's great to have that more physical, less intellectual experience of the world, I think.

PA: I know you think about animals a lot. It's an interesting way for you to come at writing an animal ...

JR: Because I myself am a shape-shifting alien?

PA: I'm reasonably sure you're not a shape-shifting alien.

JR: I'm reasonably sure too.

PA: But you've created a shape-shifting alien and then you've had that shape-shifting alien effectively imagine herself as different kinds of animals.

JR: Genius! What a great way to write about animals. I never realised I did that. You should try it. It's fun.

PA: What is it about animals, for you? For perhaps unseeable ways for the reader as well as more obvious ways, the way you think about animals manifests in your work.

JR: Perhaps it's because I don't have kids. I don't know. (Just a quick bit of psychoanalysis there.) I have quite strong relationships with my cats. I don't think it goes both ways but I have strong relationships with my cats. But there are all these other people out there who are not human people, to whom we pay so little attention. We're so interested in writing about us and we're so limited and boring. We already know a great deal about us. I would 
like to spend more time with those other non-human people out there and learn more about them and think more about what their lives might be like. I'm getting old. I'm a bit bored.

PA: As a reader, are you a bit bored?

JR: Yes! Frequently. And I read a lot. I read about a hundred books a year. Probably around a fifth of them I totally love. But there are a lot of books where 'Oh, yeah, that's nice'.

PA: Do you spend any time thinking about what sort of writer you are? When you were longlisted for the Miles Franklin Literary Award, some of the commentary around that was 'award-winning science fiction writer crosses over'. So, is she/you a spec-fic writer who has crossed over into literature or is she a literature writer who has crossed over into science fiction?

JR: I'm partly to blame for that particular take.

\section{PA: That was your marketing spin?}

JR: I chucked it out on Twitter: 'by the way, I'm the first person to win an Aurealis Award for science fiction and be longlisted for the Miles Franklin. Just a hot tip, journalists.' When I started writing, I definitely did not think of myself as a particular type of writer. I just had a lot of ideas. The only way l've found to express them is through speculative fiction. But I also don't like the chunks of information and I don't enjoy technical detail. I'm not very detail oriented. I don't like research. So, straight up science fiction wasn't going to work for me because I can't learn those things. So, this is the sort of thing that I write: literary, speculative fiction, if you call it that. I discovered that I can't write regular historical fiction. This is what I like - so it's what I write.

PA: You mentioned journalists. You trained as a journalist: is there anything about that particular type of writing that informs your practice as a novelist?

JR: Yes. I write 50,000 word novels. I also edit for succinctness: 'This word is unnecessary. Let us remove this.' I believe in editors. I feel like I'm quite a good writer to work with for the industry because $I$ accept that things get edited and stuff that's boring should go, and this isn't clear enough, it needs to be clearer. And I really respect deadlines. I think the main things I learned from journalism training are deadlines are a real thing, word counts are a real thing, you're not a genius, get the message across.

PA: That said, the messages in the fiction are not clear cut, are they?

JR: No. And From the Wreck is not clear writing. Each sentence in itself might be clear - I hope. I'm not a flowery writer. I don't describe things very much. But there's a lot of stuff going on. A lot of stuff. 
PA: I don't want to talk specifically about the ending, but I feel as if this is quite a hopeful book. There are a lot of grumpy people and grumpy aliens being grumpy about various things, but there's a strange sort of hopefulness, even as it's despairing. Do you agree?

JR: Yeah, I think so. Because I spend a lot of time worrying about the state of stuff, particularly the environment, it's that moment of joy. What are the chances of being alive? You only get to do it for a little while. It's pretty great, a lot of it. And just stopping to appreciate that every now and again can be so magical.

PA: What about the vastness of space -

JR: Good old space. Ah, so big.

PA: It's got that sense of infinity, which, for someone like me, who used to have an infinity dream, and would wake up so scared I couldn't go back to sleep, you somehow make it comforting? How do you do that?

JR: Did you find that horrible? That I would talk about that as a nice thing?

PA: Yes.

JR: I find great comfort in the idea that time is massive and space is massive and it's all going on out there around us, and this is a tiny moment in time, and a tiny moment in space, and it doesn't matter at all. How big is space. So big.

PA: So, connect that to concerns about, say, climate change. We might all die but something will survive.

JR: Something will survive. Evolution is so comforting in itself, I think. We are very attached to ourselves, obviously, but also ... tigers. Tigers are rad, but there will be another thing that will be just as amazing, in its way. Everything's amazing in its own way. And there will be other things. Hopefully we won't be around to see them? Hopefully, you know, so they get a chance.

PA: But you are also sitting around worrying about the environment.

JR: Yeah, all the time.

PA: What's particularly making you grumpy at the moment?

JR: I guess the things that make me most grumpy are ... I despair about the whole thing, frankly. The state of animals, that everything we do kills them all. We're not going to fix that.

PA: What's the role of the writer as an ideally central figure in trying to address the state of public conversation about climate change and other environmental issues? 
JR: [groans] James Bradley ${ }^{1}$ and I do a lot of panels together when we talk about this. We mostly end up saying 'Our role is to bear witness and to memorialise the death of our country.'

PA: Is there a sense that - yes, we have those panels, you get up and say what you say someone asks you the right question, you give the right answer, and the audience witness that - we can all go home believing that we've somehow done something?

JR: Yes. And that's potentially a very dangerous thing, I think, to give people the idea that they cared for a bit and their work is done now.

Patrick Allington is a Lecturer in English at Flinders University. His novel Figurehead was published by Black Inc., and his essays, short fiction and reviews have appeared widely. His novel Rise and Shrine will be published by Scribe in 2020.

\footnotetext{
${ }^{1}$ Australian novelist James Bradley is the author of many books for adults and YA readers, including most recently Clade (2015, for adults) and The Buried Ark (for YA readers).
} 